\title{
Alternative Opportunities for Small Farms: Peach and Nectarine Production Review ${ }^{1}$
}

\author{
Ali Sarkhosh, Mercy Olmstead, Jeff Williamson, Jose Chaparro, and Juanita Popenoe ${ }^{2}$
}

Florida's mild winter climate and early spring season offer unique opportunities for early-season peach and nectarine production. Currently, Florida produces some of the earliest commercial-quality peaches and nectarines in North America (Figure 1). For example, 'UFSun' and 'UFBest' peaches, which are adapted to central and south-central Florida, have a fruit development period (FDP) from bloom to harvest of approximately 80 days. When grown in south-central Florida, fruit ripens in early April and is one of the first commercial peaches to ripen in North America. It is followed closely in ripening sequence by several other peach and nectarine cultivars adapted for south-central to north Florida. During the last 12 years, the University of Florida has released many new peach and nectarine cultivars (Table 1). These new and improved cultivars have increased the potential for expansion of commercial peach and nectarine acreage throughout much of the Florida peninsula and along the Gulf Coast regions of the southeastern United States.

\section{Chilling Requirement}

Peaches and nectarines are temperate zone tree fruits that require a minimum amount of accumulated cool temperature exposure (between $32^{\circ} \mathrm{F}$ and $45^{\circ} \mathrm{F}$ ) to resume normal growth the following spring. This is referred to as the cultivar's chilling requirement (Richardson et al. 1974; Sherman and Rodriguez-Alcazar 1987; Sharpe et al. 1990). The chilling requirement is usually expressed in chill units (cu) (counts any hour between $32^{\circ} \mathrm{F}-45^{\circ} \mathrm{F}$ ) in Florida from October to first week of January. Each cultivar has its own characteristic chilling requirement, which partially determines its adaptability to a certain region of the state (Table 2; Figure 2). The importance of proper site and cultivar selection must be emphasized. For example, 'Gulfking' (350 $\mathrm{cu}$ ) is adapted to the Gainesville area, but would not receive sufficient chilling most winters to grow well south of Ocala. Conversely, if the cultivar's chilling requirement is too low for the area where it is planted, there is a greater chance of late-winter frosts killing blossoms and young fruit. More peaches and nectarines are lost to frost damage in the southeastern United States than to any other single cause.

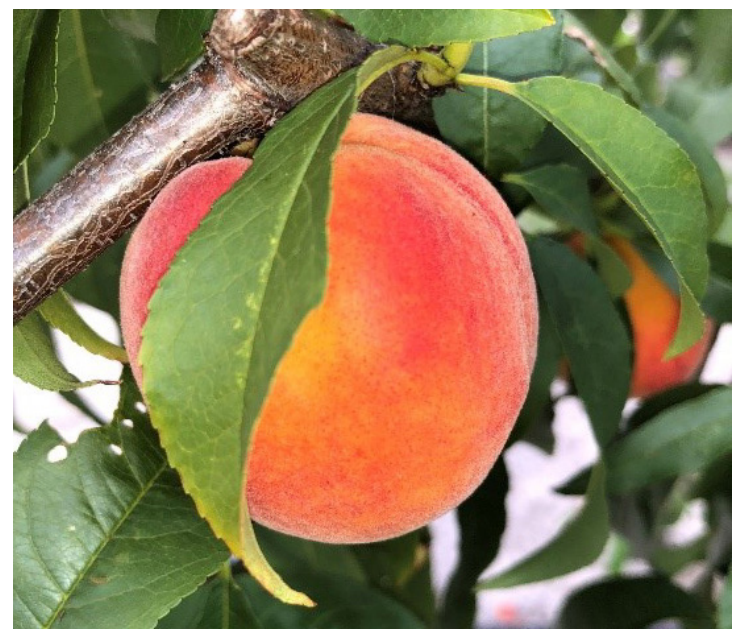

Figure 1. 'UFSun' peach.

Credits: A. Sarkhosh, UF/IFAS

1. This document is RFAC018, one of a series of the Horticultural Sciences Department, UF/IFAS Extension. Original publication date May 1987. Revised July 2018. Visit the EDIS website at https://edis.ifas.ufl.edu for the currently supported version of this publication.

2. Ali Sarkhosh, assistant professor and Extension specialist; Mercy Olmstead, former assistant professor and Extension specialist; Jeff Williamson, professor and Extension specialist; Jose Chaparro, stone fruit breeder and associate professor; Horticultural Sciences Department; and Juanita Popenoe, multi-county commercial fruit production agent IV, UF/IFAS Extension Lake County; UF/IFAS Extension, Gainesville, FL 32611. 
Table 1. Stone fruit varieties released by the UF stonefruit breeding program since 2006.

\begin{tabular}{|l|l|}
\hline \multicolumn{1}{|c|}{ Release Date } & \multicolumn{1}{c|}{ Cultivars } \\
\hline & Peach \\
\hline 2006 & FlordaBest, Gulfcrimson \\
\hline 2008 & UFOne \\
\hline 2009 & UFGlo \\
\hline 2012 & UFBest \\
\hline 2012 & GulfAtlas, Gulfsnow \\
\hline 2013 & UFGem \\
\hline 2007 & Peach Rootstock \\
\hline 2016 & Sharpe \\
\hline & MP-29 \\
\hline 2006 & Nectarine \\
\hline 2012 & UFRoyal \\
\hline & Flordarose, Southern Rose \\
\hline
\end{tabular}

Table 2. Chilling requirement characteristic of UF peach and nectarine cultivars.

\begin{tabular}{|c|l|l|}
\hline $\begin{array}{c}\text { Chill units } \\
\mathbf{3 2}^{\circ} \mathbf{F}-\mathbf{4 5}^{\circ} \mathbf{F}\end{array}$ & \multicolumn{1}{|c|}{ Cultivars } \\
\hline $500-600$ & \multicolumn{1}{|c|}{ Peach } & \multicolumn{1}{|c|}{ Nectarine } \\
\hline $400-500$ & $\begin{array}{l}\text { Gulfcrest } \\
\text { Gulfprince, Gulfcrimson, } \\
\text { Gulfsnow, 'Flordaking', } \\
\text { 'UFGlo' }\end{array}$ & \\
\hline $300-400$ & $\begin{array}{l}\text { Flordadawn, UF2000, } \\
\text { Flordacrest, Gulfking, } \\
\text { UFSharpe }\end{array}$ & Sundollar, 'Suncoast' \\
\hline $200-300$ & $\begin{array}{l}\text { UFBeauty, UFGold, } \\
\text { TropicSnow, 'UFOne', } \\
\text { 'UFO','Flordabest' }\end{array}$ & $\begin{array}{l}\text { UFRoyal, Sunraycer, } \\
\text { Sunmist, UFQueen }\end{array}$ \\
\hline $100-200$ & $\begin{array}{l}\text { UfSun, UFBest, UFGem, } \\
\text { Flordaprince, Flordaglo, } \\
\text { TropicBeauty }\end{array}$ \\
\hline
\end{tabular}

\section{Marketing Situation}

The incentives for growing peaches and nectarines in Florida are 1) production and marketing of fresh Florida peaches and nectarines before central Georgia, South Carolina, and California enter the market, and 2) production of quality fruit when there is almost no other quality fresh fruit of any kind available (Figure 3). Peaches and nectarines can be produced continuously from late March until late May or early June in Florida, depending on weather. As precipitation increases during the summer months, disease and pest problems on peaches and nectarines also increase. Later-maturing cultivars have little or no potential in Florida because of increased pest and disease pressure and increased market competition.

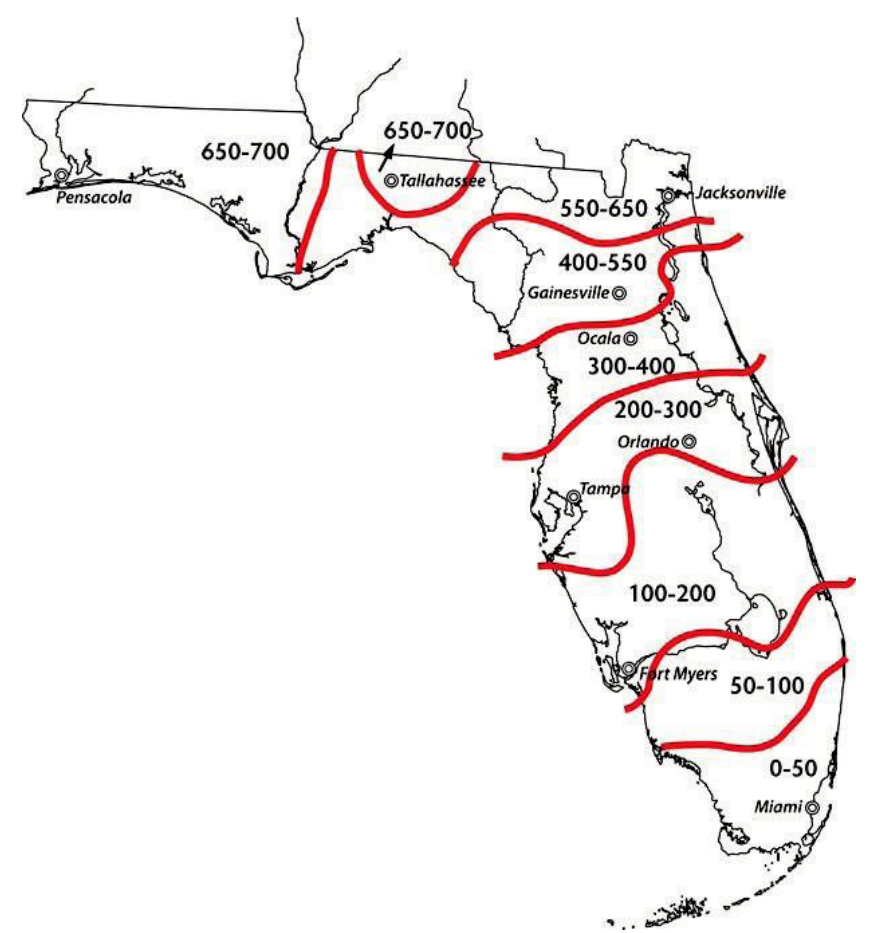

Figure 2. Chill units accumulated (between $32^{\circ} \mathrm{F}$ and $45^{\circ} \mathrm{F}$ ) through February 10 in $75 \%$ of winters.

Credits: UF/IFAS

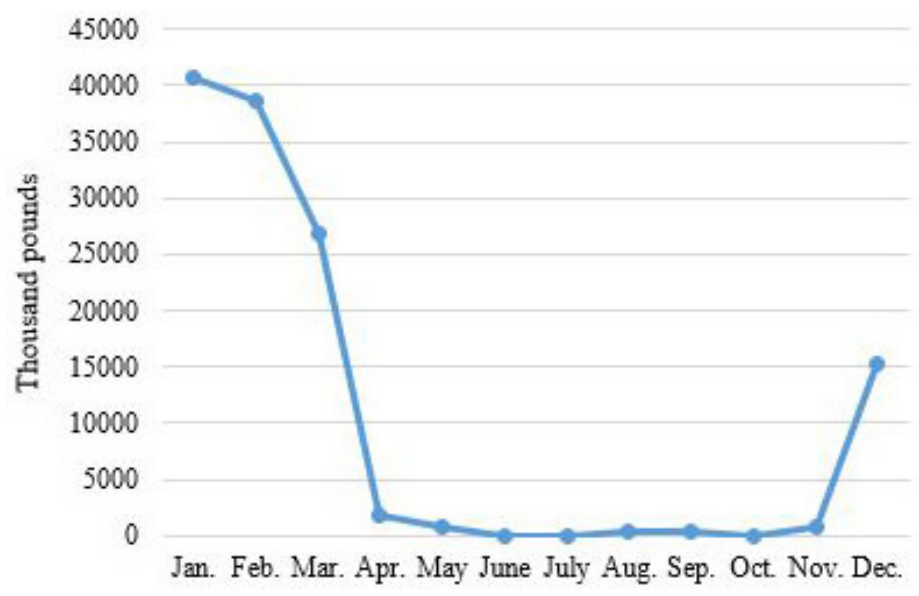

Figure 3. Average monthly imports of peaches and nectarines (2001-2011).

Credits: Economic Research Service, USDA-ARS

To market high-quality peaches, it is necessary to harvest each cultivar three to four times at two-day intervals in order to obtain fruit that are "tree ripe." When harvested at this stage, the fruit has highest potential for flavor. For long-distance shipment, fruit must be carefully handled, graded, sized, cooled, and packed. This requires a sizeable investment in a packinghouse, which is not likely to prove economically feasible with much less than 100-150 acres. However, marketing alternatives for smaller growers include joining a grower cooperative, making direct sales to grocery stores or produce markets, and opting for U-pick, farmers' markets, or roadside stand operations. It is important to grow several cultivars that ripen in succession to 
ensure a steady flow of ripe fruit. This longer harvest period helps with marketing and efficient use of harvest labor and packing facilities.

Commercial peach and nectarine operations in the southeastern United States can have preharvest production costs of about $\$ 4,000$ per acre (Morgan et al. 2010, M. Olmstead pers. comm.). For more information about production cost and profitability of peach orchard please visit EDIS publication https://edis.ifas.ufl.edu/pdffiles/FE/FE101600. pdf (Singerman et al. 2017). These initial costs vary if the land is already purchased and irrigation is available from a previous crop. Because marketing costs for commercial orchards are relatively high, U-pick operations have the potential of greatly reducing total costs. Estimated returns (gross) to peach growers in Florida are approximately four to five times greater than those of growers in surrounding southeastern states (United States Agricultural Statistics Board 2011).

\section{Labor}

Peach and nectarine production requires high levels of seasonal hand labor. Commercial growers hire labor for dormant and summer pruning, fruit thinning, and harvesting. Family operations often supply their own labor. Timing of labor operations is especially critical; often a delay of a few days in harvesting can result in profit loss. Currently, the greatest cost of peach production in Florida is hand thinning and manual pruning. These practices together require around 150 hours per acre depending on tree size and fruit set, resulting in an estimated annual cost of $\$ 2,000 /$ acre.

\section{Planting Guidelines}

Peaches and nectarines should only be planted on sites with excellent air drainage to reduce the risk of frost damage to flowers. Cold air is denser and sinks to the lowest spot in the orchard, especially on nights with radiation freezes. Radiation freezes occur on clear nights with calm wind conditions, where warm air rises as the cold air sinks (Figure 4). An advective freeze is dominated by windy conditions and often results in severe damage to the flowers and potential fruit. On a good site, select cultivars with chilling requirements slightly less than the average chilling received in that location. This helps ensure adequate chilling during unusually warm winters; if the site has excellent air drainage, the risks of flower damage from spring freezes will be minimal during normal and high-chill years.

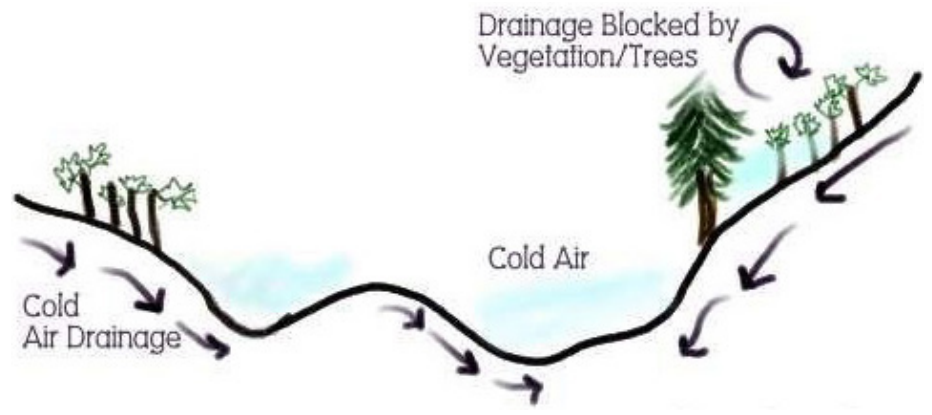

Figure 4. Site selection criteria for a stone fruit orchard. Credits: M. Olmstead, UF/IFAS

Site selection (http://agroclimate.org/tools/chill-hoursmonitoring/) and cultivar choice (http://edis.ifas.ufl. edu/pdffiles/MG/MG37400.pdf) rank as the two most important factors in successful peach and nectarine growing. When selecting a site, avoid low areas characterized by late spring frosts. Even in central Florida, freezes can occur throughout February and early March in cold locations; thus, sites with good air drainage are essential for reliable production. Planting an orchard with the proper site and variety will allow growers to maximize their establishment efficiency with the minimum number of replanted trees. Historical and current weather data for a particular orchard site can be found using https://fawn.ifas.ufl.edu/.

Peaches and nectarines can be grown on a wide variety of soils, provided they are well-drained in the upper 4 to 6 feet of soil. Avoid "hardpan" soils unless an excellent system of subsoil drainage tiles or bedded systems are provided. Irrigation is required for tree growth and throughout the fruit development period to obtain acceptable fruit size and yields. A properly designed overhead sprinkler irrigation system has the added advantage of protecting flowers and young fruit from late winter and spring freezes. For lowvolume irrigation systems, micro-sprinklers are preferred to drip emitters. To avoid spraying seedlings/trees truck with water, micro-sprinklers with 240 to 300 degrees spraying pattern are recommended.

June-budded trees that are $2 \frac{1}{2}$ to 4 feet high are a good size to plant during the fall season, while larger sizes are more difficult to handle and expensive. Normal tree spacing is $15 \times 20$ feet, or 145 trees per acre. On lighter soils, higher density plantings have been satisfactory (Table 3). All Florida peach and nectarine cultivars are self-fruitful and should be planted in solid blocks for easier spraying and harvesting. 
Table 3. Various tree and row spacing for orchard establishment.

\begin{tabular}{|c|c|c|}
\hline $\begin{array}{c}\text { Spacing between } \\
\text { trees (feet) }\end{array}$ & $\begin{array}{c}\text { Spacing between } \\
\text { rows (feet) }\end{array}$ & Total trees/acre \\
\hline 15 & 25 & 117 \\
\hline 15 & 20 & 145 \\
\hline 10 & 20 & 218 \\
\hline 10 & 15 & 290 \\
\hline
\end{tabular}

\section{Cultural Program}

Growing peaches and nectarines requires a high level of skilled management, which includes pruning, fruit thinning, harvesting, and scouting for pests and diseases (Figure 5). Peaches and nectarines are susceptible to a number of pests, including diseases, insects, and nematodes. Root-knot nematodes (Meloidogyne incognita and M. javanica) are common in Florida soils and can negatively affect the health of peach and nectarine trees. In addition, the newly identified peach root-knot nematode, $M$. floridensis (Handoo et al. 2004), can infect common peach rootstocks such as 'Nemaguard' and 'Okinawa.' Therefore, only a $M$. floridensis root-knot nematode-resistant rootstock such as 'Flordaguard' should be used in Florida (Sherman et al. 1991). An integrated pest management program must be followed to ensure good fruit quality. Although some diseases and insects can be severe, they can usually be controlled with a proper pest management program. A disease and pest management guide is available online at https://secure.caes.uga.edu/extension/publications/files/ pdf/B\%201171_11.PDF. More information is available on the University of Florida Stone Fruit website (http://hos. ufl.edu/extension/stonefruit) and from your local UF/IFAS Extension office.

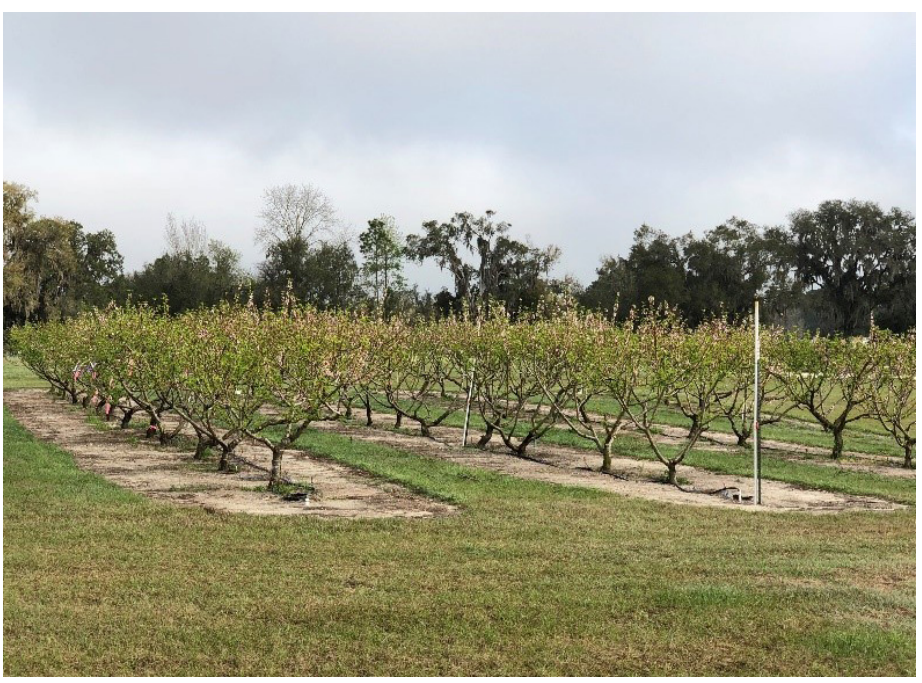

Figure 5. Peach orchard at the University of Florida research farm located in Citra.

Credits: A. Sarkhosh, UF/IFAS

\section{References}

Handoo, Z. A., A. P. Nyczepir, D. Esmenjaud, J. G. van der Beek, P. Castagnone-Sereno, L. K. Carta, A. M. Skantar, and J. A. Higgins. 2004. "Morphological, Molecular, and Differential-Host Characterization of Meloidogyne floridensis $\mathrm{n}$. Sp. (Nematoda: Meloidogynidae), a Root-Knot Nematode Parasitizing Peach in Florida." Journal of Nematology. 36(1): 20-35.

Morgan, K., J. Braswell, F. Matta, D. Ingram, and B. Layton. 2010. Peach - Fruit and Nut Planning Budgets. Starkeville: Mississippi State University.

Richardson, E. A., S. D. Seeley, and D. R. Walker. 1974. "A Model for Estimating the Completion of Rest for 'Redhaven' and 'Elberta' Peach Trees.' HortScience. 9(4): 331-332.

Sharpe, R. H., W. B. Sherman, and J. D. Martsolf. 1990. "Peach Cultivars in Florida and Their Chilling Requirements." Acta Horticulturae. 279: 191-197.

Sherman, W. B., and J. Rodriguez-Alcazar. 1987. "Breeding of Low-Chill Peach and Nectarines for Mild Winters." HortScience. 22: 1233-1236.

Sherman, W. B., P. M. Lyrene, and R. H. Sharpe. 1991. “"Flordaguard' Peach Rootstock." HortScience. 26(4): 427-428.

United States Agricultural Statistics Board. 2011. "Noncitrus Fruits and Nuts 2010 Summary." http://usda. mannlib.cornell.edu/MannUsda/viewDocumentInfo. do?documentID $=1113$ 